\title{
IDENTIFICATION OF MANGROVE FOREST DAMAGE, AND EFFORT TO CONSERVATION IN BALIKPAPAN CITY, EAST KALIMANTAN, INDONESIA
}

\author{
Yaskinul Anwar ${ }^{1}$, Iya' Setyasih ${ }^{2}$, Ardiansyah ${ }^{3}$, Dwi Partini ${ }^{4}$, Ratih Puspita Dewi ${ }^{5}$, Yunus Aris Wibowo ${ }^{6}$ \\ ${ }^{1,2,3}$ Geography Education, Universitas Mulawarman \\ ${ }^{4}$ Geography Education, Universitas Pattimura \\ ${ }^{5,6}$ Geography Education, Universitas Muhammadiyah Surakarta \\ Email: yaskinul.anwar@fkip.unmul.ac.id
}

\begin{abstract}
The rapid development of Balikpapan City has an impact on the increasingly high demand for land for urban expansion needs. The expansion of Balikpapan City is more directed towards coastal areas which are dominated by mangrove forests. This study discusses the destruction of the mangrove forest and its causal factors and how conservation efforts are being carried out to maintain sustainability. Mangrove forest damage data obtained through surveys and image analysis using NDVI. While the factors causing the damage to mangrove forests were obtained from observations and interviews with the mangrove center manager of Balikpapan. The results showed that there were many mangrove forests that had rare or already damaged that were spread in the West Balikpapan, North Balikpapan, and East Balikpapan Sub-district. This damage is caused by natural and non-natural factors. Natural factors that cause damage to mangrove forests are pests and sedimentation. The non-natural factors are due to the pollution and the opening of fish ponds. Preservation efforts are carried out by replanting mangroves which are only carried out by the mangrove center and some CSR and environmentalists and do not involve the community at large. These Conditions make the mangrove forest in Balikpapan City threatened its sustainability.
\end{abstract}

Keywords: Mangrove Damage; Conservation; NDVI

\section{A. INTRODUCTION}

Balikpapan City is one of the gateways of East Kalimantan as well as the most developed city in Kalimantan, even more after being designated as the Indonesian Oil and Gas Logistics Center area in 2015. The development of Balikpapan City can also be seen from the establishment of Industrial Estates in the Kariangu Area of 2,189.93 Ha (Spatial Planning Balikpapan City 2012 - 2032, 2012) which will expand the urban area of Balikpapan City. In addition, the expansion of the oil refinery area will also increasingly expand the urban area towards the coastal area which is a mangrove forest area.

The development of cities towards the coast will continue to change the function of urban suburbs (Felsenstein \& Lichter, 2014). The suburban area of Balikpapan which has a morphology that is suitable to be used as an urban area is a mangrove forest. The mangrove forest area of Balikpapan City in 2017 was 3,150 hectares (Warsidi \& Endayani, 2017). The extensive area of mangrove 
forests in the city of Balikpapan is mostly located in the west which is mostly located in the city development and industrial areas of the Kariangu and oil refineries.

This study discusses the destruction of the mangrove forest and its causal factors and how conservation efforts are being carried out to maintain sustainability. Mangrove forests have very large functions and benefits for humans (Lee et al., 2014), although most of the mangrove damage is caused by human activities. Mangrove forest areas can provide economic benefits, timber for commercial, agricultural purposes, and as a shelter or land opening for fish, shrimp or crab ponds (Mukherjee et al., 2014). The greater the benefits / economic benefits obtained, the greater the environmental damage it will cause so that today many mangrove forests are damaged and even destroyed. Based on this, it is necessary to conduct research to identify damage and efforts to preserve mangrove forests in the City of Balikpapan.

Various conservation strategies have been developed to support the sustainability of coastal ecosystems with varied results (Feka \& Morrison, 2017). Among these is the use of the ecosystembased conservation approach, which is gaining widespread acceptance in global political agendas as a sustainable option with numerous co-benefits and can be used to reduce pressures caused by both anthropogenic and natural activities (Green et al., 2005). In order to conserve mangrove forests in Balikpapan City, a conservation forest area has been established in Margomulyo and Mangrove Center Giri Indah (Hendra, 2014). The mangrove forest protection area in these two locations is only \pm 150 hectares, so it is still not optimal in protecting mangrove forests in Balikpapan City first in the suburban areas.

Mangrove forest areas on the urban fringe are often conversion due to land needs in urban areas. Land-use change is often caused by economic, socio-cultural and technological changes (Giyarsih, 2010). Changes in the area of mangrove forests are not only caused by land conversion but also mangrove forests damage (Thomas et al., 2017).

Damage to mangrove forests can be detected quickly with remote sensing technology. The criteria that can be used to identify mangrove damage with Sentinel 2 imagery can be reflected in the value of the NDVI (Normalized Difference Vegetation Index) (Kamthonkiat et al., 2011, Sari \& Rosalina, 2016, Akbar et al., 2020, Pujiono et al., 2013). The location of 
mangrove forests, which are mostly located in areas where access is difficult and requires a long time, will make monitoring difficult. The use of remote sensing technology can provide time efficiency and effectiveness of funds in monitoring mangrove forest damage (Richards \& Friess, 2016).

Mangrove forests damage, some of which is caused by pressure and rapid increase in population, especially in coastal areas, resulting in changes in land use and excessive use of natural resources. In addition, community activities around the area of mangrove forests also play a role in the destruction of mangrove forests. This community activity is influenced by socio-economic conditions, education and community knowledge about mangrove forests (Nchimbi, 2019). Community economic activity is a major factor influencing the preservation of mangrove forests. Economic activities in coastal areas are often uncontrolled and economic community people are often not aware of the importance of efforts to preserve natural resources in coastal areas, especially mangrove forests (Dahuri et al., 1996).

\section{B. MATERIALS AND METHODS}

\section{Location}

Administratively, Balikpapan City has a land area of $503.3 \mathrm{~km}^{2}$ and marine management area reaches $160.1 \mathrm{~km}^{2}$. Balikpapan City is located at position $116.50^{\circ}-117.00^{\circ} \mathrm{W}$ and between $1.00^{\circ}$ $1.50^{\circ} \mathrm{S}$. Balikpapan City is a city that has mangrove forest with a total area of 2,784.16 Ha (Figure 1). This mangrove forest is spread in West Balikpapan District (88.55 Ha), North Balikpapan District (1890.02 Ha) and East Balikpapan District (805.59 Ha). 


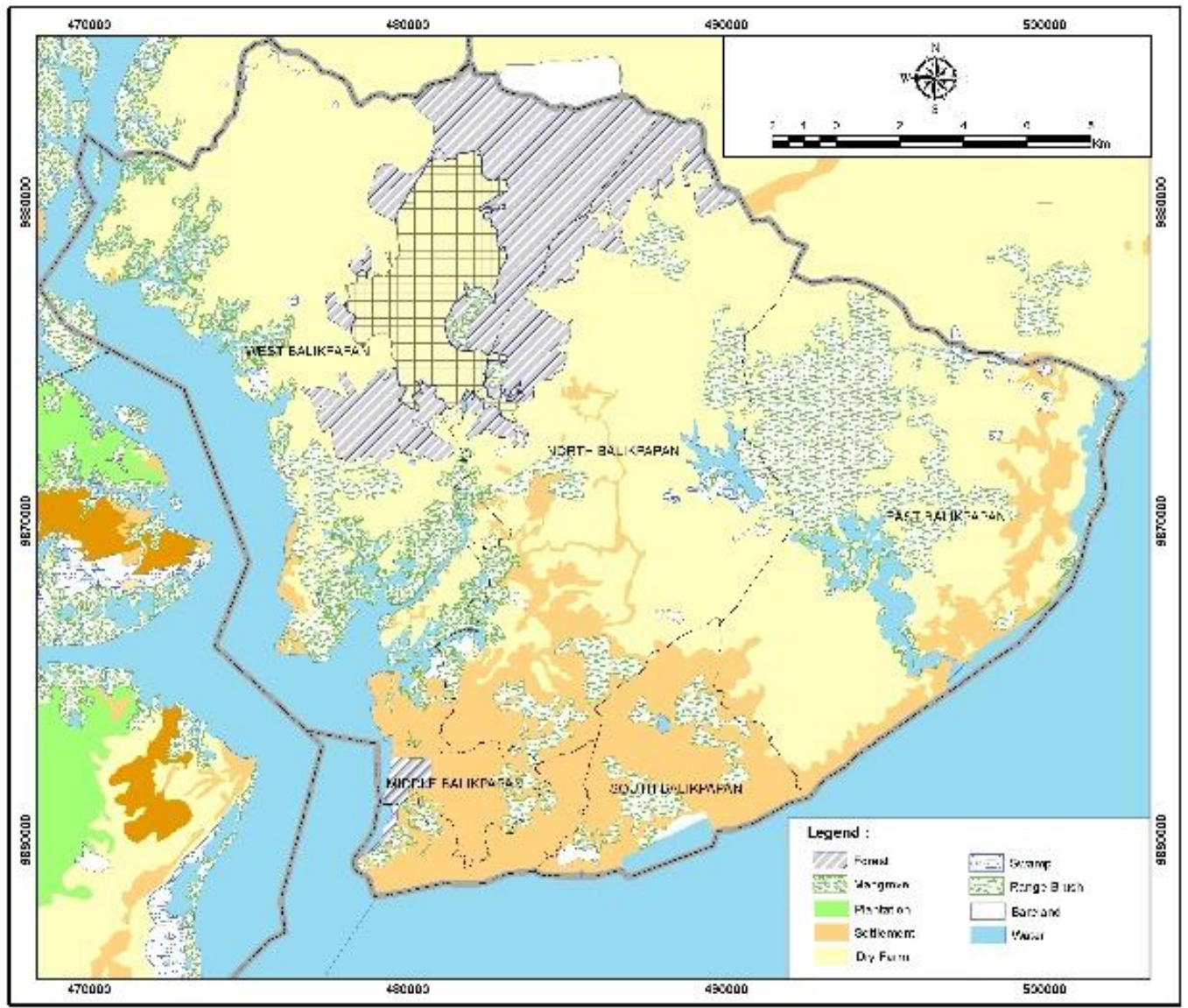

Figure 1. Landuse Map Balikpapan City

\section{Mangrove Damage Identification and}

To know the condition of mangrove using the density value of the mangrove forest from Sentinel 2 ( $2^{\text {nd }}$ June 2018), the ratio of the near infrared band (NIR) and the red band(Waas \& Nababan, 2010) (Sari \& Rosalina, 2016) (Umroh et al., 2016) is used with the formula below:

$N D V I=\frac{(N I R-R E D)}{(N I R+R E D)}$

Information :

NDVI : Normalized Difference Vegetation Index

NIR : Near infrared wave

RED : Red wave

After the NDVI results are obtained then a ground check to see and obtain the real condition of mangroves in Balikpapan City. Factors that cause damage to mangrove forests are identified through observation and interviews in order to obtain information on damage and caused of damage.

\section{Conservation Effort}

To collect data on conservation efforts in the city of Balikpapan, conducted through interviews. Respondents were selected from the community around the mangrove forest, the mangrove care community, and the mangrove center manager. 


\section{RESULTS AND DISCUSSION}

\section{Mangrove Forest Damage}

Based on the results of the NDVI analysis, the vegetation density of the mangrove forest can be obtained which can be used as a ground check to determine the damage of mangrove forests in the Balikpapan City. The NDVI results that have been grounded, found that the area of damaged mangroves reached 1092.41 Ha (Figure 2). Damaged mangrove forests are spread throughout the mangrove forests in Balikpapan City (Figure 2 and 3).

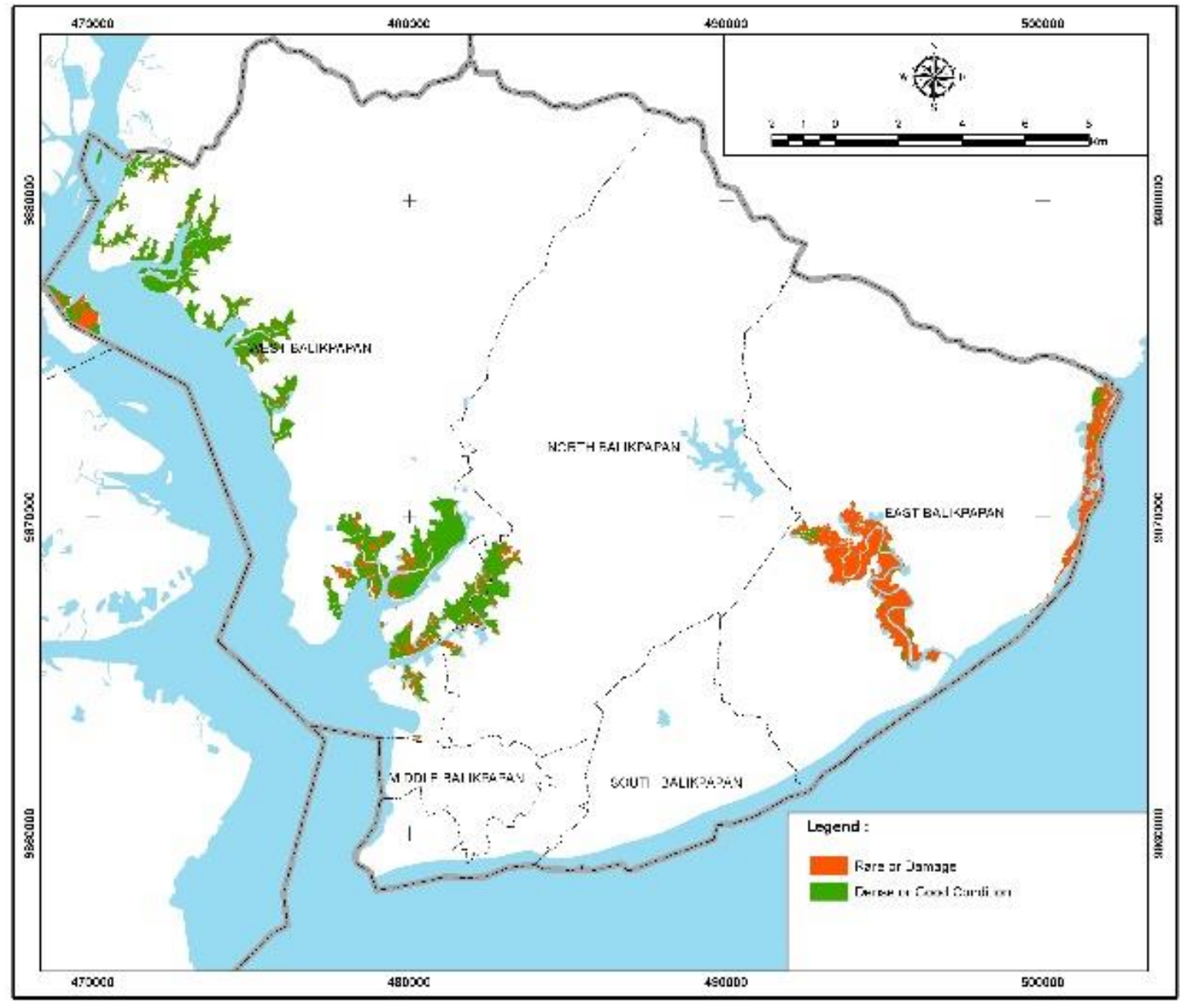

Figure 2. Map of Mangrove Condition in Balikpapan 


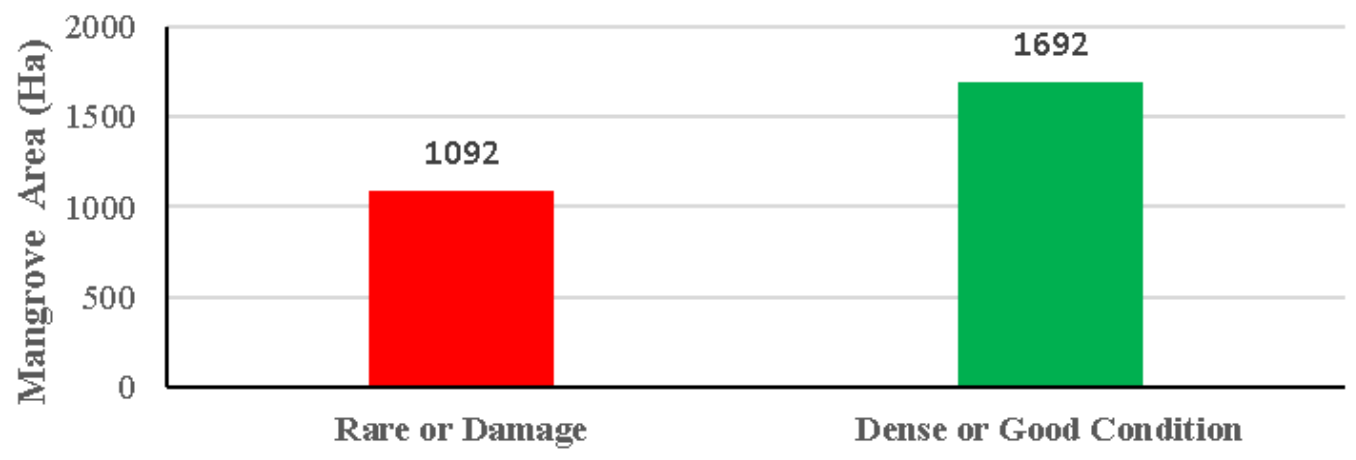

Figure 3. Graph of Mangrove Condition in Balikpapan.

Mangrove forest damage is caused by various factors both from natural factors and due to human activities in the city of Balikpapan. Natural factors that damage mangrove forests are high sedimentation. These sediments often cover mangrove roots, especially for the types of Pneumatophore or aerial root, and cause mangrove death due to disruption of metabolism (Ellison, 1999). The conditions found around the coast
Tritip of East Balikpapan that similar to the mangrove dieback, where the front of the mangrove has died, and there are no saplings that grow around it (Figure 4 (a)). This sediment originates from rivers that flow into the coastal area in Balikpapan City. This sedimentation only affects mangrove forest areas which are on sloping beaches, because the sediment will quickly cover the aerial roots of the mangrove.

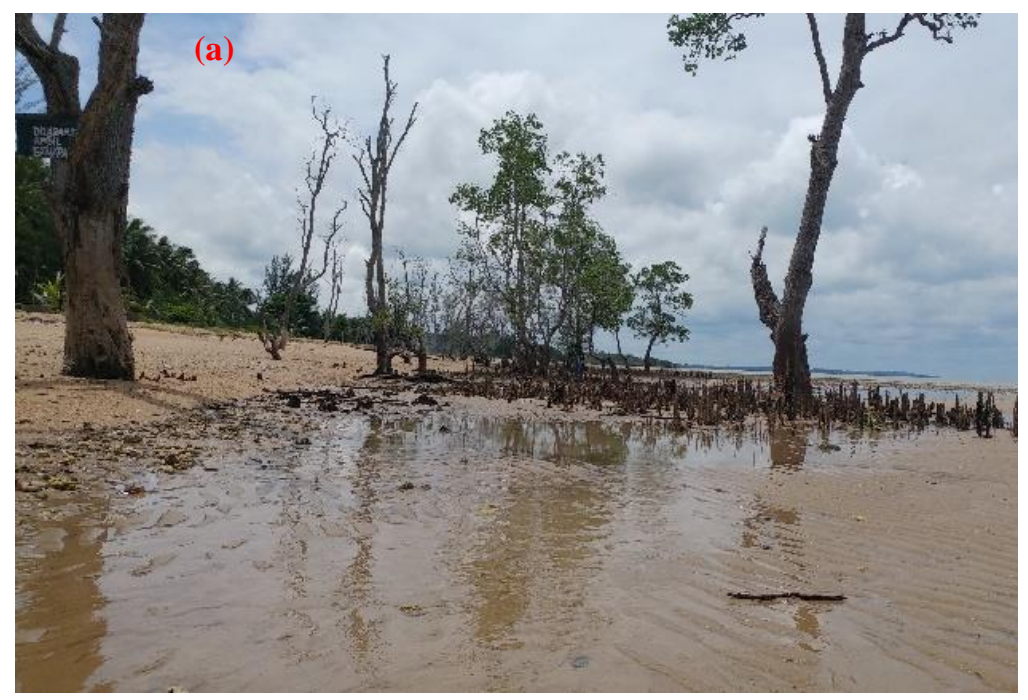


(b)

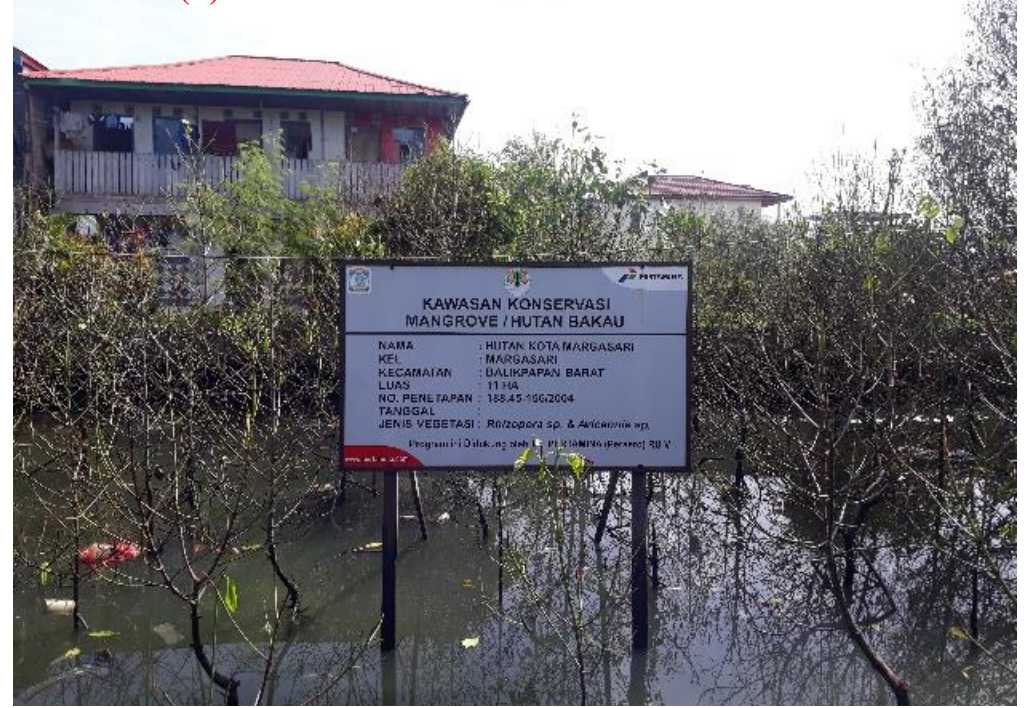

Figure 4. Mangrove Die (a) Caused of High Sediment and (b) Caused Oil Spill

Factors of human activity that are quite damaging to mangrove forests include oil spills, waste, and landconversion. Balikpapan City is the largest oil mining city in Indonesia with drilling carried out both in the coastal and offshore areas. The vulnerability of oil spills around Balikpapan City is very high both from oil leaks from the oil tanker and oil pipelines. Oil spill from the oil pipeline in Balikpapan bay on 30 March 2018 has caused damage to some mangrove forests around the Balikpapan bay. When the oil is spilled in the waters, the oil will settle to the coastal area that is exposed during the tides (Huz et al., 2005). this deposition often covers and attaches to the soil and roots which are very sensitive parts of the mangrove tree which often causes the death of mangroves (Duke, 2016) (Diez et al., 2019). The most damage was found around West and North Balikpapan, where not only mangrove saplings died but also trees (Figure 4 (b)). The effects of oil spills require a long time to recover because oil spills not only make mangroves die but also make the soil toxic and difficult to grow mangroves naturally. 

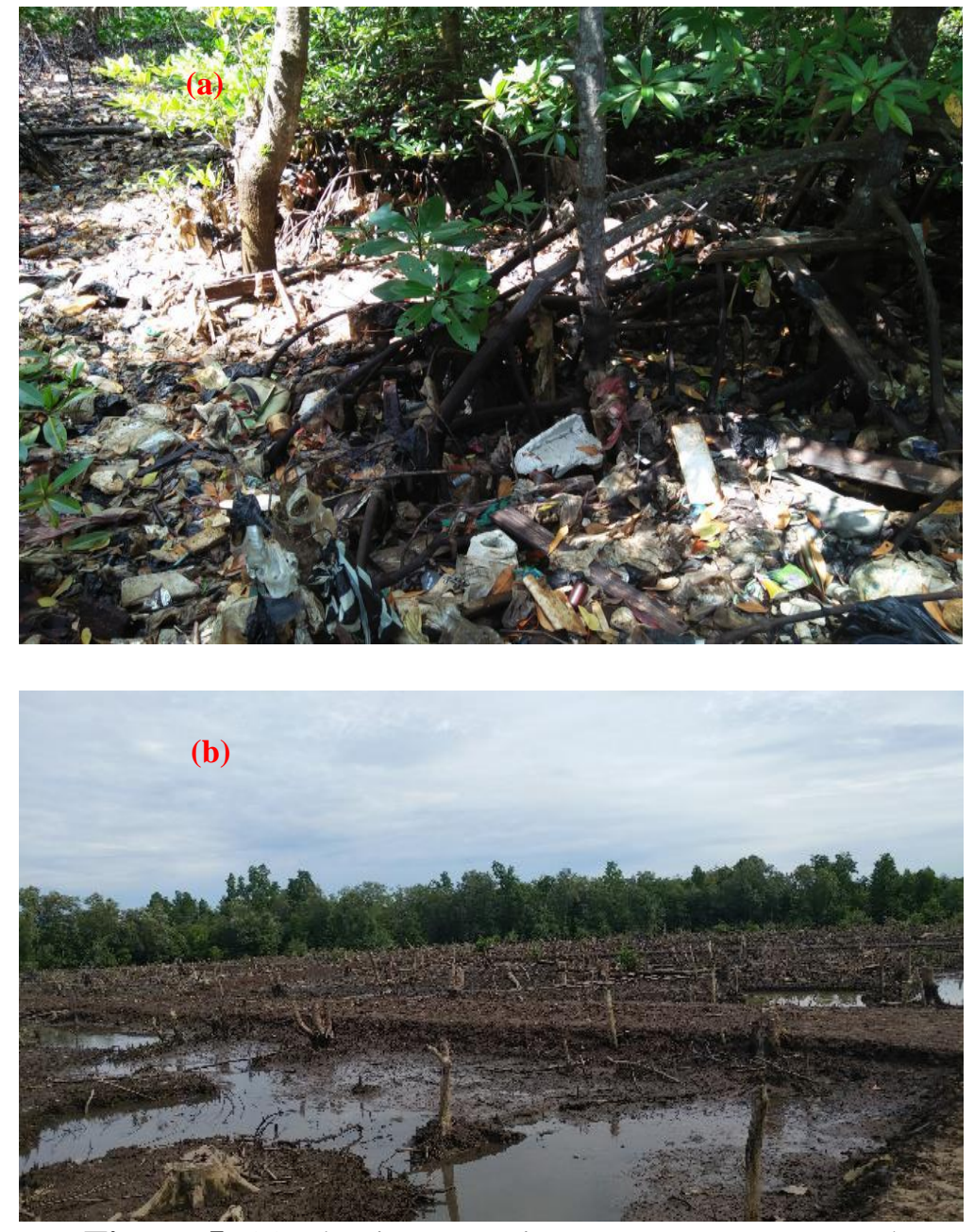

Figure 5. (a) Plastic Waste in Mangrove Forest and (b) Mangrove Area Conversion to be Settlement area

Domestic waste and industrial waste also play a role in increasing damage to mangrove forests. The main source of pollution from Balikpapan City is waste from housing, hotels, restaurants and market activity. This waste is not considered by residents of Balikpapan City that often pollutes coastal areas, especially mangrove forests. The type of waste that is commonly found around mangrove forests is plastic waste that cannot be decomposed in a fast period (Diez et al., 2019). The waste will disturb mangroves as the newly growing saplings will be covered up by plastic which cannot grow and die (Figure 5 (a)). This condition is mostly found in mangrove forests around river mouths that pass through settlements in the city of Balikpapan. Many mangroves have rare density because mangrove seeds cannot grow on plastic waste. The impact of plastic waste does not seem to have a major effect like the effect of oil spills, but plastic waste increases every day and collects and also covers the mangrove 
plants. So, in a long period, plastic waste can cause mangrove damage on an ongoing basis that is greater than the oil spill.

The human activity factor that also destroys the mangrove forest area is a land conversion of mangrove forest. Land conversion of mangrove forests in coastal urban areas is difficult to avoid because of the demand for land to support urban development (Alongi, 2002). Mangrove forest areas are often converted into functions for both residential and industrial land needs. The increasing number of settlements and industries in the city of Balikpapan leads to coastal areas dominated by mangrove forests (Figure 5 (b)). The development of settlements in the mangrove forest area is more related to the ease of transportation that is closer to urban areas and cheaper land prices in the area. Whereas for industry, it is seen from the easy access to send and receive goods through water access, so that many industries are located near the coast or river in Balikpapan Bay that dominated by mangrove.

\section{Mangrove Forest Conservation Efforts}

Efforts to conserve mangrove forests that have been damaged in order to restore the function of mangrove forest ecosystems have actually been done by the government (especially Mangrove
Center), Corporate Social Responsibility (CSR), as well as people who care about the environment. However, this effort is constrained by private or corporate property rights, which are not possible to do because of the difficulty of permission from the landowner. As for the efforts that have been made by both the government, CSR and the Society of environmentalists is to replant damaged mangrove areas. After replanting, the area is also cared, especially cleaning of plastic waste. It's like in the Margomulyo mangrove forest, where every Friday morning Pertamina CSR and people who care about the environment, clean the plastic waste in the Margomulyo mangrove forest and replanting dead mangroves.

Replanting mangroves is not easy because of pollution constraints both from waste and oil spills. Planting techniques to protect from waste, especially plastic rubbish, are to put a net on a replanting area (Figure 6), such as the mangrove area in Margomulyo, North Balikpapan, which places nets to protect newly planted mangroves. The use of nets helps protect newly planted mangrove seeds from piledup garbage, especially plastic waste. Disposal of garbage around the coast and also rivers in the city of Balikpapan is very high, so during floods or high tides, water often carries plastic waste that can cover newly planted mangroves. 


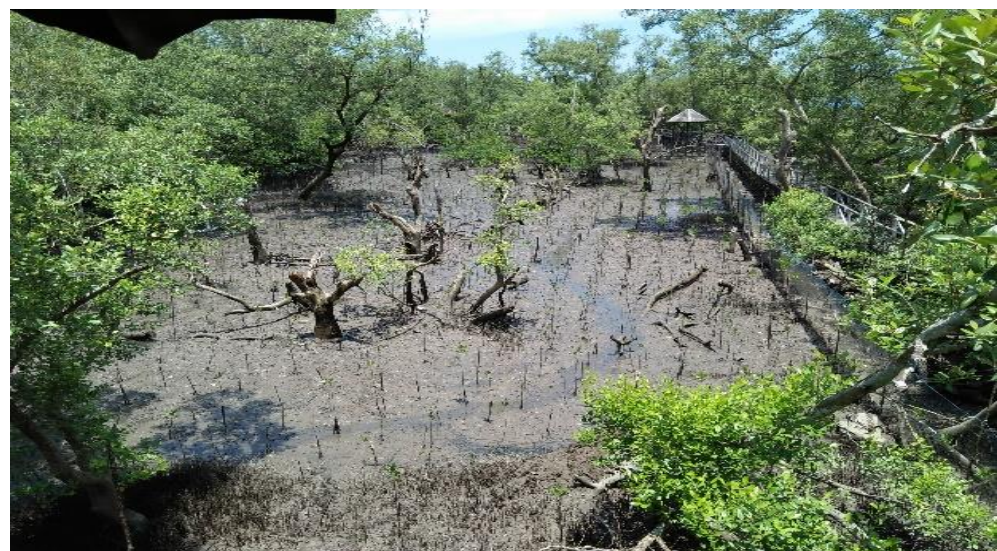

Figure 6. Net for protecting replanting area from plastic waste

Closure of plastic waste in a long time will cause the newly planted mangrove will die. Meanwhile, to prevent oil spills is quite difficult, so that many mangrove seeds that have just been planted die because oil spill (Figure 7), such as near the village over the water of Margasari, West Balikpapan, which died due to oil spills on 30 March 2018. Oil spills have the potential to destroy mangroves because of their toxicity (Ghozali et al., 2017). So although the occurrence of oil spills are rare, the impact of one oil spill causes many mangroves to die.

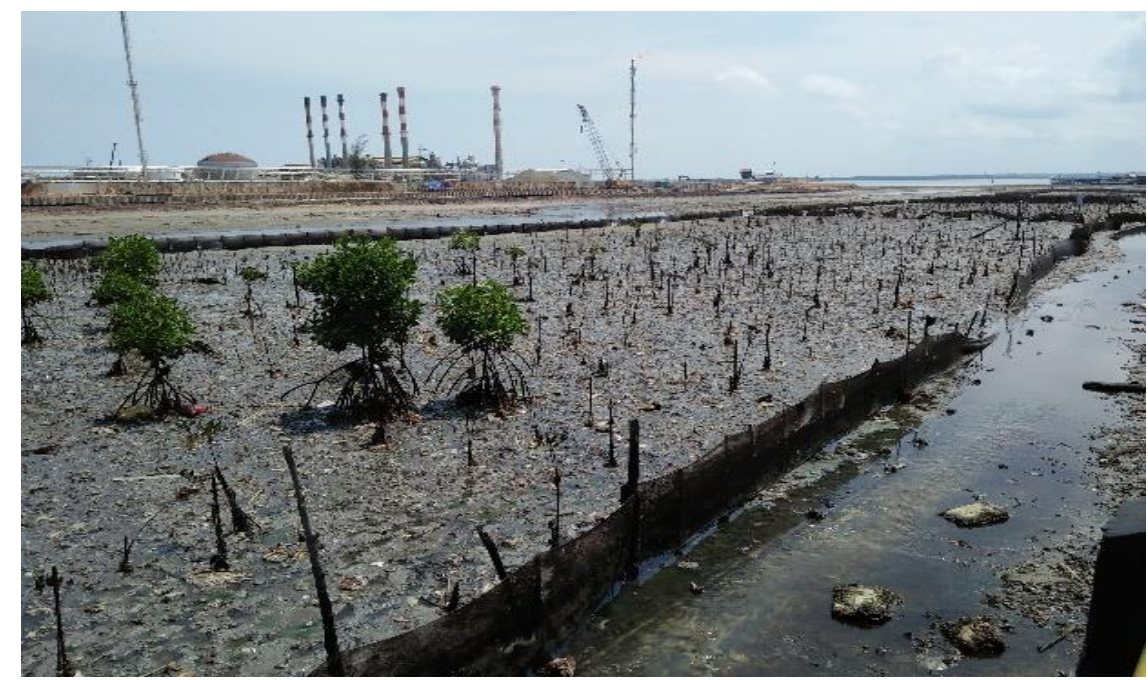

Figure 7. Mangrove seeds die after oil spill

In addition, efforts to preserve mangrove forests are carried out by making the mangrove area as ecotourism and educational tourism area. The mangrove forest area in Balikpapan City which is used as a tourist area is the mangrove forest in Margomulyo and Graha Indah (Mangrove Center). By 
becoming ecotourism and educational tourism area, mangrove forests in this area are expected can be preserved (Friess, 2017). But the area of this ecotourism area is not too wide (16 Ha for Mangroves Margomulyo and 150 Ha for Mangroves Graha Indah). This condition is not comparable with the total area of mangrove forests that need to be preserved (2,784.16 Ha).

Based on these conditions, it is necessary to have regulations governing restrictions on permits for the conversion of mangrove forests, waste management in Balikpapan City, as well as efforts to minimize oil spills due to industrial activities and. In addition, it is also necessary to foster a sense of community concern for the environment in order to minimize domestic waste, and also care to restore the damaged mangrove forest environment. The lack of sense of community concern for the mangrove forest area can be seen from the behavior of people who still often littering and also the small number of people who want to participate in planting and caring for mangroves in the Coastal City of Balikpapan.

\section{CONCLUSIONS}

Mangrove damage in the city of Balikpapan has greatly damaged the mangrove forest area, which is spread in three districts. The causes of damage to mangrove forests are natural and human factors such as sedimentation, oil spills, waste, and land conversion. This damage is inevitable due to population growth and land needs as well as increased industrial activity in the city of Balikpapan. Conservation efforts are carried out by replanting damaged mangrove forests and carrying out maintenance by protecting them with nets and cleaning plastic waste. This activity only limited to government-owned land, while for community or company land it is still difficult to do. In addition, conservation is only carried out by the government (mangrove center), CSR, and the community concerned about the environment, so that conservation efforts are less effective.

\section{E. ACKNOWLEDGMENTS}

The research team would like to thank the Faculty of Teacher Training and Education Mulawarman University, East Kalimantan, for the support of founding during the research. Thanks to the mangrove center that support of mangrove data in Balikpapan City. The author would like thank to Darul Sopianto and Indriyani Anikmah Ardi for data collection and support during this study. 


\section{F. REFERENCES}

Akbar, M. R., Arisanto, P. A. A., Sukirno, B. A., Merdeka, P. H., Priadhi, M. M., \& Zallesa, S. (2020). Mangrove vegetation health index analysis by implementing NDVI (normalized difference vegetation index) classification method on sentinel-2 image data case study: Segara Anakan, Kabupaten Cilacap. IOP Conference Series: Earth and Environmental Science. https://doi.org/10.1088/17551315/584/1/012069

Alongi, D. M. (2002). Present State and Future of the World' s Mangrove Forests Present state and future of the world ' s mangrove forests. Environmental Conservation, 29(December), 331-349. https://doi.org/10.1017/S037689290 2000231

Spatial Planning Balikpapan City 2012 2032, $32 \quad$ (2012). http://jdih.balikpapan.go.id/index.ph $\mathrm{p} /$ component/remository/funcstartdown $/ 416 /$ ? Itemid $=477$

Dahuri, R. R., Ginting, J. S. ., \& Sitepu, M. J. (1996). Integrated Coastal Resource Management. Pradya Paramita.

Diez, S. M., Patil, P., Morton, J., Rodriguez, D. J., Vanzella, A., Robin, D., Maes, T., \& Corbin, C. (2019). Marine Pollution in the Caribbean: Not a Minute to Waste. Washington, D.C. http://documents.worldbank.org/cur ated/en/482391554225185720/pdf/ Marine-Pollution-in-the-CaribbeanNot-a-Minute-to-Waste.pdf

Duke, N. C. (2016). Oil spill impacts on mangroves: Recommendations for operational planning and action based on a global review. $M P B$. https://doi.org/10.1016/j.marpolbul. 2016.06.082

Ellison, J. C. (1999). Impacts of Sediment
Burial on Mangroves. Marine Pollution Bulletin, 37(98), 420-426.

Feka, Z. N., \& Morrison, I. (2017). Managing mangroves for coastal ecosystems change: A decade and beyond of conservation experiences and lessons for and from westcentral Africa. Journal of Ecology and The Natural Environment, 9(6), 99-123.

https://doi.org/10.5897/JENE2017.0 636

Felsenstein, D., \& Lichter, M. (2014). Ocean \& Coastal Management Land use change and management of coastal areas: Retrospect and prospect. Ocean and Coastal Management, 101, 123-125. https://doi.org/10.1016/j.ocecoaman .2014.09.013

Friess, D. A. (2017). Ecotourism as a tool for Mangrove Conservation. Sumatra Journal of Disaster, Geography and Geography Education, 1(1), 24-35. http://sjdgge.ppj.unp.ac.id/index.php /Sjdgge/article/view/32

Ghozali, A. A., Kusmana, C., Iswantini, D., \& Nurhidayat, N. (2017). Oil contamination in mangrove ecosystems: Impacts and rehabilitations. AACL Bioflux, 10(6), 1711-1721. https://doi.org/AACL Bioflux 10(6):1711-1721

Giyarsih, S. R. (2010). Urban Sprawl of The City Of Yogyakarta, Special Reference To The Stage of Spatial Transformation (Case Study at Maguwoharjo Village, Sleman District). Indonesian Journal of Geography, 42, 47-58. https://doi.org/doi.org/10.22146/ijg. 1576

Green, R. E., Balmford, A., Crane, P. R., Mace, G. M., Reynolds, J. D., \& Turner, R. K. (2005). A framework 
for improved monitoring of biodiversity: Responses to the world summit on sustainable development. In Conservation Biology. https://doi.org/10.1111/j.15231739.2005.00289.x

Hendra. (2014). Konservasi Mangrove Balikpapan dan Keseimbangan Ekspansi Pembangunan. Https://Www.Mongabay.Co.Id/. https://www.mongabay.co.id/2014/0 3/31/konservasi-mangrovebalikpapan-dan-keseimbanganekspansi-pembangunan/

Huz, R. de la, Lastra, M., Junoy, J., Castellanos, C., \& Vie'itez, J. M. (2005). Biological impacts of oil pollution and cleaning in the intertidal zone of exposed sandy beaches : Preliminary study of the " Prestige " oil spill Biological impacts of oil pollution and cleaning in the intertidal zone of exposed sandy beaches: Prelimina. Estuarine, Coastal and Shelf Science, 65, 1929.

https://doi.org/10.1016/j.ecss.2005.0 3.024

Kamthonkiat, D., Rodfai, C., Saiwanrungkul, A., Koshimura, S., \& Matsuoka, M. (2011). Geoinformatics in mangrove monitoring: Damage and recovery after the 2004 Indian Ocean tsunami in Phang Nga, Thailand. Natural Hazards and Earth System Science, 11(7), 1851-1862. https://doi.org/10.5194/nhess-111851-2011

Lee, S. Y., Primavera, J. H., DahdouhGuebas, F., Mckee, K., Bosire, J. O., Cannicci, S., Diele, K., Fromard, F., Koedam, N., Marchand, C., Mendelssohn, I., Mukherjee, N., \& Record, S. (2014). Ecological role and services of tropical mangrove ecosystems: A reassessment. Global Ecology and Biogeography. https://doi.org/10.1111/geb.12155

Mukherjee, N., Sutherland, W. J., Huge, D., Koedam, N., \& Dahdouh-Guebas, F. (2014). Ecosystem Service Valuations of Mangrove Ecosystems to Inform Decision Making and Future Valuation Exercises. PLoS ONE, 9(9), 1-9. https://doi.org/10.1371/journal.pone .0107706

Nchimbi, A. A. (2019). Socioeconomic Determinants of Mangrove Exploitation and Seagrass Degradation in Zanzibar: Implications for Sustainable Development. 2019, 11. https://doi.org/https://doi.org/10.115 5/2019/7684924

Pujiono, E., Kwak, D., Lee, W., Kim, S., Lee, Y., Lee, S., Park, T., Kim, M., Pujiono, E., Kwak, D., Lee, W., \& Kim, S. (2013). RGB-NDVI color composites for monitoring the change in mangrove area at the Maubesi Nature Reserve, Indonesia. Forest Science and Technology, 9(4), 171-179. https://doi.org/10.1080/21580103.20 13.842327

Richards, D. R., \& Friess, D. A. (2016). Rates and drivers of mangrove deforestation in Southeast Asia, 2000-2012. Proceedings of the National Academy of Sciences of the United States of America, 113(2), 344-349.

https://doi.org/10.1073/pnas.151027 2113

Sari, S. P., \& Rosalina, D. (2016). Mapping and Monitoring of Mangrove Density Changes on tin Mining Area. Procedia Environmental Sciences. https://doi.org/10.1016/j.proenv.201 6.03 .094

Thomas, N., Lucas, R., Bunting, P., Hardy, A., Rosenqvist, A., \& Simard, M. (2017). Distribution and drivers of 
global mangrove forest change, 1996-2010. PLoS ONE. https://doi.org/10.1371/journal.pone .0179302

Umroh, Adi, W., \& Sari, S. P. (2016). Detection of Mangrove Distribution in Pongok Island. Procedia Environmental Sciences. https://doi.org/10.1016/j.proenv.201 6.03 .076

Waas, H. J. ., \& Nababan, B. (2010).
Mapping and Index Analysis Mangrove Vegetation on Saparua Island, Central Maluku. E-Jurnal Ilmu Dan Teknologi Kelautan Tropis.

Warsidi, \& Endayani, dan S. (2017). Mangrove Vegetation Composition In Balikpapan Bay East Kalimantan Province. Jurnal AGRIFOR, XVI, 115-124. 